Please cite as: Adelle, C., Weiland, S., Dick, J., González, D., Marquart, J., Rots, G., Wübbeke , J., Zasada, I. (2016) Regulatory Impact Assessment: A Survey of Selected Developing and Emerging Economies. Public Money and Management, 36(2) 89-96.

\title{
Regulatory Impact Assessment: A Survey of Selected Developing and Emerging Economies
}

Camilla Adelle, Centre for the Study of Governance Innovation, Department of Political Sciences, University of Pretoria, Pretoria, South Africa. Camilla.adelle@up.ac.za

Camilla Adelle is a Senior Research Fellow at the Centre for the Study of Governance innovation at the University of Pretoria.

Sabine Weiland, Environmental Policy Research Centre (FFU), Freie Universität Berlin, Berlin, Germany. sabine.weiland@fu-berlin.de

Sabine Weiland is a senior research fellow at FU Berlin. She is working on sustainability and environmental governance and knowledge use in policy-making.

Jan Dick, Centre for Ecology and Hydrology, Bush Esate, Penicuik, Midothian, EH26 0QB, UK. jand @ceh.ac.uk

Jan Dick is a senior landscape ecologist researching social-ecological coupled systems, from policy and practice perspectives.

Diana González Olivo, Leibniz Centre for Agricultural Landscape Research (ZALF), Müncheberg, Germany and University of Potsdam, Germany, diana.gonzalez.olivo@uni-potsdam.de

Diana González Olivo worked as a research fellow Leibniz Centre for Agricultural Landscape Research and now works at the University of Potsdam, Germany.

Jens Marquardt, Environmental Policy Research Centre (FFU), Freie Universität Berlin, Berlin, Germany.jens.marquardt@fu-berlin.de

Jens Marquardt is lecturer and PhD fellow at the Freie Universität Berlin, working on environment and energy related issues in Southeast Asia.

George Rots, Alterra Wageningen University and Research Centre, Wageningen, The Netherlands. George.rots@wur.nl

George Rots works in the Environmental Risk Assessment team of Alterra, a research institute for the green living environment.

Jost Wübbeke, Leibniz Centre for Agricultural Landscape Research (ZALF), Müncheberg, Germany and Mercator Institute for China Studies, Berlin, Germany. Jost.Wuebbeke@merics.de Jost Wübbeke worked as a research fellow at the Leibniz Centre for Agricultural Landscape Research and now works at the Mercator Institute for China Studies, Berlin.

Ingo Zasada, Institute of Socio-Economics, Leibniz Centre for Agricultural Landscape Research (ZALF), Müncheberg, Germany.

Ingo.zasada@zalf.de

Ingo Zasada is a post-doctoral research fellow working on agricultural and landscape policies and planning 


\begin{abstract}
This article reports on an in depth survey of the practice of Regulatory Impact Assessment (RIA) in 16 developing and emerging economies. It reveals that RIA is playing an increasing role in these countries: eight have introduced RIA in the last ten years; one has recently redesigned its existing RIA system; another has a longstanding RIA system in place. However, RIA still remains at an early stage of development in the majority of cases and six countries do not practice RIA.
\end{abstract}

\title{
Key Words
}

Developing countries; regulatory impact assessment; better regulation; regulatory reform; policy appraisal

\section{Introduction}

Regulatory Impact Assessment (RIA) involves a systematic appraisal of the social, economic and environmental impacts of proposed regulations and other kinds of policy instruments before they are adopted. RIA is now almost universally practiced by members of the Organisation of Economic Cooperation and Development (OECD) and European Union (EU) as a key tool for improving the efficiency, transparency and accountability of regulatory decision making (Kirkpatrick, 2015; Adelle and Weiland, 2012). In addition, the demand for RIA in developing and emerging economies is thought to be growing (OECD, 2008). The need for effective regulatory structures in these countries is now well recognised and in many cases RIA has been adopted as part of donor financed regulatory reform programmes which aim to improve the business environment and quality of public governance in these countries (Parker and Kirkpatrick, 2007; World Bank, 2009).

A sizable academic literature charts the diffusion and practice of RIA in developed countries (see Adelle et al., 2012 for a review). However, relatively little is known about the use of RIA in developing and emerging economies (but see Adelle et al., 2015). This is partly because information on the topic often does not reach the public domain as it is frequently only available in the project and programme documents of the international agencies and donors promoting regulatory reform (Kirkpatrick, 2015). Nevertheless, over a decade ago Kirkpatrick et al. (2004) provided details of the practice of RIA in 30 developing and transition countries based on the results of a questionnaire to economic regulators. This revealed that, while a number of developing and emerging economies were beginning to apply some form of regulatory assessment, awareness of RIA in many jurisdictions was still low and the development of RIA remained at an early stage. But has the situation changed in the last decade?

In order to improve the knowledge base on which to successfully implement RIA in developing countries, it is vital that research on RIA examines not only practices in 
OECD and EU member states, but also scrutinizes global practices. This knowledge should be of interest not only to governments of developing and emerging economies attempting to institutionalize RIA but also the many international donor organisations and governments in developed countries that are attempting to promote and support RIA in the developing world. For example, in the UK where RIA has been practiced some form of policy assessment since the mid 1980s, the Department for International Development as well as the Better Regulation Delivery Office in the Department of Business Innovation and Skills are involved in supporting RIA in developing countries both technically and financially. Both the OECD and the World Bank are also strong advocates of the adoption of RIA by governments in developing countries. This article therefore seeks to help fill an important knowledge gap by focusing on the current state of RIA practice in developing and emerging economies. It does so through an in depth survey of RIA in 16 developing and emerging economies.

\section{The Survey}

The countries included in the survey (see Table 2) were selected on the grounds that they were (mainly) included on the World Bank list of developing countries (World Bank, 2013), and that they collectively represented a sample of different parts of the developing world (i.e. countries from Africa, Asia, and Latin America). Where possible, countries were selected where RIA activities were known to be occurring. Two selected cases merit further explanation: Mexico has been an OECD member since 2006 but is still on the World Bank's list of developing countries; the United Arab Emirates is not on this list but was included in the survey in order to partly capture an apparent rising interest in RIA in the Gulf States. All of the countries selected, however, are included in the category of 'developing and emerging economies' in the sense that they are outside the OECD's Development Assistance Committee (DAC) membership (OECD, 2014).

Two approaches were used to gather data. First, a desk-based analysis of relevant RIA literature and documents (RIA reports, draft and final legal texts, policy documents and external evaluations) provided a broad picture of how RIA is conducted. Second, where possible, semi-structured elite interviews were conducted for each country with those people who at a strategic level champion, oversee, guide, audit or write guidance for RIA processes. These interviews allowed information from the documentary sources to be verified, helped fill remaining information gaps as well as brought to light new documentary sources. This information was compiled in a standardised template that focused on several aspects of the RIA systems (see below).

We adapted the following definition of RIA from Radaelli et al. $(2006$, p. 5) as:

1. A systematic and consistent assessment of aspects of social, economic, or environmental impacts such as benefits and/or costs;

2. affecting interests external to the government;

3. of proposed regulations and other kinds of legal and policy instruments; 
4. to i) inform policy decisions before a regulation, legal instrument, or policy is adopted; or ii) assess external impacts of regulatory and administrative practices; or iii) assess the accuracy of an earlier assessment.

Furthermore, rather than just the once off use of RIA, the survey sought to identify more systematic and sustained efforts to institutionalise, or embed, RIA across government and regulatory agencies at least, for example, in the form of a pilot project. Thus the survey looked for evidence of the institutionalisation of 'RIA systems' rather than just 'RIA events'. Based on the RIA literature (and explained in more detail below) we developed a set of criteria for evaluating the extent to which these are embedded in the policy making process. These are set out in Table 1 and include aspects to do with: the origins and purposes of RIA; the institutional framework; transparency and consultation; as well as tools and methods.

Table 1. Criteria for evaluating the extent to which 'RIA systems' are embedded in the policy making process

\begin{tabular}{|c|c|}
\hline Purpose and Origin of RIA \\
\hline$\bullet \quad$ Is RIA legally mandated or endorsed at a politically high level? \\
\hline Institutional Framework \\
\hline$\bullet \quad$ Is the coverage of RIA consistent? (in terms of which policy proposals have RIAs performed \\
on them) \\
\hline$\bullet \quad$ Is the practice of RIA consistent? (in terms of if they follow the RIA guidance) \\
\hline$\bullet \quad$ Is there a central oversight and coordination unit? \\
\hline$\bullet \quad$ Is there provision for training? \\
\hline Transparency and Openness \\
\hline$\bullet \quad$ Are the RIA reports easily accessible to stakeholders? \\
\hline$\bullet \quad$ Is consultation mandatory and systematic? \\
\hline Tools and Methods \\
\hline Is the use specific tools and methods (e.g. Cost Benefit Analysis) encouraged in guidance \\
\hline documents etc? \\
\hline Quality of RIA \\
\hline & Is the RIA system perceived by external evaluations to be adequate? \\
\hline & Are there significant barriers to RIA? \\
\hline
\end{tabular}

\section{Results}

\section{Origins and purposes of RIA}

Of the 16 developing and emerging economies included in the survey, ten had established, or were in the process of establishing, institutional frameworks for RIA (South Africa, Uganda, Tanzania, Cambodia, Laos, Philippines, Malaysia, Vietnam, Brazil and Mexico). Of these countries, only Mexico (an OECD member) had a longstanding RIA system. Many of the other countries were in the very early stages of developing an RIA system, and in some cases had not yet gone much beyond a pilot phase (South Africa ${ }^{1}$, Brazil (Pro-Reg), ${ }^{2}$ and the Philippines). Table 2 shows the countries included in the survey and the status of their RIA systems.

\footnotetext{
1 In South Africa support for RIA has fallen so low that there are strong indications that it is soon to be replaced by an alternative 'Socio-Economic Impact Assessment System'.
} 
Table 2. The practice of RIA in developing and emerging economies

\begin{tabular}{|c|c|}
\hline Country & Status of RIA \\
\hline \multicolumn{2}{|l|}{ Africa } \\
\hline South Africa & RIA introduced in 2007 \\
\hline Tanzania & RIA introduced in 2004 \\
\hline Uganda & RIA introduced in 2004 \\
\hline \multicolumn{2}{|l|}{ Asia } \\
\hline Cambodia & RIA introduced in 2008 \\
\hline China & No RIA framework in place \\
\hline India & No RIA framework in place \\
\hline Laos & RIA introduced in 2011 \\
\hline Malaysia & Ad hoc pilot RIAs for over ten years; RIA more formally introduced in 2013 \\
\hline Philippines & The need for RIA identified in 2006 but RIA is still in the early stages of development \\
\hline Vietnam & RIA introduced in January 2009 \\
\hline \multicolumn{2}{|c|}{ Latin America } \\
\hline Brazil & $\begin{array}{l}\text { The 'Pro-Reg' programme established in } 2007 \text { but is still in the early stages of } \\
\text { development. } \\
\text { 'Inmetro' developed RIA methodology in } 2007 \text { and started producing RIA reports in } \\
2009 \text {. }\end{array}$ \\
\hline Chile & No RIA framework in place \\
\hline Colombia & No RIA framework in place \\
\hline Ecuador & No RIA framework in place \\
\hline Mexico & $\begin{array}{l}\text { 'Pre-RIA' practiced since the early 1990s; more contemporary RIA introduced } \\
\text { around } 2000\end{array}$ \\
\hline \multicolumn{2}{|r|}{$M_{1}$} \\
\hline UAE & No RIA framework in place \\
\hline
\end{tabular}

Six countries included in the study did not appear to have, or be in the process of developing, a formal RIA system (China, India, United Arab Emirates, ${ }^{3}$ Colombia, Chile and Ecuador). In most of these cases the policy making systems contained many of the elements found in formal RIA systems in developed countries (e.g. an explanation of the rational/ objectives of the policy proposal; stakeholder consultation; a outline of anticipated impacts) but these were not part of a wider framework for RIA and/or did not qualify as full RIAs according to Radaelli et al.'s (2006) definition. For example, in 2010 Chile introduced an assessment of social and economic impacts of new proposals affecting Small and Medium Sized Enterprises (SMEs) but this is much narrower than a full RIA. Similarly, in Ecuador, a technical parliamentary committee uses a checklist to assess the consistency, constitutionality of proposed regulatory proposals from a legal point of view but this can also not be considered a full RIA. Furthermore, in the UAE certain emirates (such as Abu Dhabi) have under taken pilot RIAs while at the same time the federal level 'Regulation and Supervision Bureau' supports the use of RIA in certain circumstances. While in India its introduction is frequently discussed, RIA is only applied on an ad hoc basis, e.g. in the infrastructure and business sector, these initiatives are fragmented and issue

\footnotetext{
2 Brazil has two decentralised RIA systems: first, the Pro-Reg programme was established in 2007 with technical support from the OECD to promote and develop RIA capacity within regulatory agencies in Brazil; second, a single regulatory agency, 'Inmetro', independently developed its own RIA methodology in 2007 and started producing its first RIA in 2009.

3 There is apparently some interest from the Gulf states, including the United Arab Emirates, in considering regulatory reform programmes including RIA in the near future.
} 
specific. These six countries without formal RIA systems are not considered further in this article.

In the ten 'RIA-countries' the survey looked at how RIA was first established. A formally announced or even a legally mandated RIA system endorsed by the head of government or senior minister, is essential - but not sufficient - to ensure that regulators comply with the RIA requirement set out in RIA Guidelines or other procedural arrangements for government decision making (World Bank, 2009). Of the ten countries included in which RIA has or is being established, RIA is legally mandated in four (Laos, Vietnam, Malaysia and Mexico). Furthermore, the Philippines intend to put in place an Executive Order for the mandatory implementation of RIA across the Government in 2015. While Inmetro in Brazil claims that their system is mandatory (interview 2), this is only within their own institutional framework and RIA is not imposed by central government. In South Africa, Tanzania and Uganda RIA is not legally binding, although in the cases of South Africa and Tanzania, RIA had been formally approved or endorsed by high-up government officials (Truen, 2011; ICAS, 2010a). In Uganda, despite RIA being included in a large-scale programme of regulatory reform, approval for the requirement to include RIA in policy/legislation submissions to Cabinet has not been obtained (Opio-Lukone, 2008).

The overarching motivation for introducing RIA set out in the official documents in all ten countries is to improve the business environment. The thinking underlying this is that RIA can deliver a business environment that is characterized by greater transparency, accountability and consistency in the development and application of regulations, a focus on minimizing unnecessary and excessive regulation and even help address corruption. In some countries (Vietnam, Philippines and Tanzania) RIA is specifically mentioned as a tool to transform historically autocratic and/or socialist systems into market driven economies and (in the case of Vietnam) accession to the World Trade Organization (APEC Economic Community, 2009; Welch, 2007). In Cambodia RIA is linked to the need to be ready for increased competition following the integration of the Association of Southeast Asian Nations (ASEAN) into an economic community in 2015 (Nolson, 2014). In Uganda 'Better Regulation' and RIA more specifically is seen as a key tool to achieve its economic growth targets (Welch, 2007). Similarly, in South Africa RIA was introduced with the aim of improving the regulatory environment for SMEs, which are seen as critical to the success of the economy (SBP, 2005; interview 1). In Malaysia, attempts to establish a strong and reliable RIA is argued to ensure that the country's regulatory regime 'supports the nations aspirations to become a high-income economy by 2020' (Hamsa, 2013, p. 5).

The majority of the RIA systems have been established with the involvement of international donor agencies and organizations. The OECD played a significant technical role in establishing RIA in Brazil through the Pro-Reg programme while both the OECD and the Inter-American Development Bank provided technical and financial support to Malaysia in its attempts to set up RIA. In the Philippines, Cambodia and Laos, the Asian Development Bank supports the implementation of RIA through its technical assistance programme. In Tanzania, RIA was introduced as 
part of the much wider programme 'Business Environment Strengthening for Tanzania' (BEST) supported by four donors, including the UK's Department for International Development (DFID) (Welch, 2007, p. 202). DIFID also sponsored the introduction of RIA in Uganda under the Regulatory Best Practice Programme (ibid). In Vietnam RIA was established with support from its Administrative Procedure Control Agency, the German organisation GTZ, and the USAID's Vietnam Competitiveness Initiative (Truen, 2011).

\section{Institutional framework}

The survey attempted to gain information on the institutional framework of RIA in the different countries as well as the extent to which this framework is being applied in practice, for example by following the RIA guidance documents setting out how RIA should be practiced in a particular context. The results reveal that the coverage of the RIA systems varies considerably between the different countries. RIA is apparently being systematically and widely applied in only relatively few instances (Mexico, Vietnam, and Inmetro in Brazil). In the majority of the other countries (South Africa, Tanzania, Uganda, Cambodia, Laos, Malaysia, Philippines, and ProReg in Brazil), RIA is implemented in a fairly ad hoc fashion, often as part of an official pilot phase. In certain cases (e.g. South Africa) few RIAs reports were ever conducted after the end of the pilot phase in 2009. On the other hand, in Cambodia, a successful pilot of RIA in four ministries from 2011-2013 led to the addition of three new ministries in 2013 and a gathering momentum for the wider institutionalisation of RIA across government (Nolson, 2014). In addition, the extent to which the institutional frameworks in the 'RIA-countries' in practice actually resemble those described in the RIA guidelines or handbooks also varies both between and within countries. An external assessment of RIA in Tanzania argues that the guidelines should more be interpreted as 'a statement of intent rather than a description of actual practice' (ICAS, 2010a, p.14).

The coordination and oversight of RIA by a central unit is seen by the World Bank as essential in ensuring that the framework for RIA set out in the guidelines is translated into practice by government departments (World Bank, 2009). These units are often located in central government departments or offices such as the Cabinet or Presidency Office. The survey found central RIA units in almost all RIA systems examined (see Table 3) (except Pro-Reg and Inmetro in Brazil and Laos). However, many, if not most, of these central RIA units suffered from serious capacity and/or political issues, including under-staffing and inter-institutional conflict (ICAS, 2010b; The Presidency, 2006).

Besides RIA guidelines or handbooks training on RIA is an essential component of a best practice RIA system (World Bank, 2009). Such training efforts must be maintained over the long term. In most of the countries included in the survey training has been a major feature of the attempts to establish RIA systems. This has often been supported by international donor organizations and RIA experts. For example, in Vietnam a series of workshops were held during 2004 with the support of USAID - some 2,500 government officials received practical training on RIA. In 
Table 3. Central RIA Units and other institutional support for RIA

\begin{tabular}{|c|c|c|}
\hline Country & Location of central RIA unit & Other institutional support for RIA \\
\hline \multicolumn{3}{|l|}{ Africa } \\
\hline South Africa & $\begin{array}{l}\text { A Central RIA Unit is located in the } \\
\text { Presidency. }\end{array}$ & $\begin{array}{l}\text { Departmental RIA units champion RIA } \\
\text { within each department (in theory). The } \\
\text { Treasury also offers technical support. }\end{array}$ \\
\hline Tanzania & $\begin{array}{l}\text { The Government's Better Regulation } \\
\text { Unit is in the Office of the President. }\end{array}$ & $\begin{array}{l}\text { The Office of the Cabinet Secretariat is } \\
\text { the focal point for RIA compliance. }\end{array}$ \\
\hline Uganda & $\begin{array}{l}\text { An RIA Unit was embedded in the Policy } \\
\text { Analysis and Coordination Unit within } \\
\text { the Office of the Cabinet Secretariat. } \\
\text { However, the task of institutionalizing } \\
\text { RIA has now been given to a new } \\
\text { Department of Policy Development. }\end{array}$ & $\begin{array}{l}\text { The Ministry of Tourism, Trade and } \\
\text { Industry also has a Regulatory Best } \\
\text { Practice Unit which evaluates the } \\
\text { business compliance costs of new } \\
\text { policies. Other RIA focal points exist in } \\
\text { the five ministries piloting RIA. }\end{array}$ \\
\hline \multicolumn{3}{|l|}{ Asia } \\
\hline Cambodia & $\begin{array}{l}\text { The Office of Regulatory Impact } \\
\text { Assessment is embedded the Economic, } \\
\text { Social and Cultural Council within the } \\
\text { Office of the Council of Ministers. }\end{array}$ & $\begin{array}{l}\text { RIA units are also embedded within each } \\
\text { of the ministries piloting RIA. }\end{array}$ \\
\hline Laos & $\begin{array}{l}\text { An RIA inter-agency taskforce, chaired } \\
\text { by the vice minister for industry and } \\
\text { commerce, was established in } 2009 \text {. } \\
\text { The Ministry of Industry and Commerce } \\
\text { also established an RIA unit in } 2011 \text {. }\end{array}$ & $\begin{array}{l}\text { RIA units have been set up in the three } \\
\text { other ministries which have agreed to } \\
\text { pilot RIA as well as the Economic Planning } \\
\text { and Finance Committee of the National } \\
\text { Assembly. }\end{array}$ \\
\hline Malaysia & $\begin{array}{l}\text { The National Development Planning } \\
\text { Committee oversees the } \\
\text { implementation of the RIA process. }\end{array}$ & $\begin{array}{l}\text { The Malaysia Productivity Corporation } \\
\text { reviews RIA; the National Institute of } \\
\text { Public Administration is responsible for } \\
\text { RIA training; there is an RIA coordinator } \\
\text { in each ministry. }\end{array}$ \\
\hline Philippines & $\begin{array}{l}\text { An inter-agency RIA steering committee } \\
\text { oversees the development and } \\
\text { implementation of the RIA pilot } \\
\text { programme. }\end{array}$ & $\begin{array}{l}\text { Each participating department has } \\
\text { established an internal RIA committee. } \\
\text { The inter-agency RIA steering committee } \\
\text { is supported by the Ministry of Finance. }\end{array}$ \\
\hline Vietnam & $\begin{array}{l}\text { A central RIA unit is located in the } \\
\text { Ministry of Justice. }\end{array}$ & $\begin{array}{l}\text { The Prime Minister's Research Council } \\
\text { also champions RIA across government. }\end{array}$ \\
\hline \multicolumn{3}{|l|}{ Latin America } \\
\hline Brazil & $\begin{array}{l}\text { Pro-Reg and Inmetro - There is no } \\
\text { central governmental RIA unit as the } \\
\text { initiative is located within individual } \\
\text { regulatory agencies. }\end{array}$ & $\begin{array}{l}\text { Pro-Reg and Inmetro - This depends on } \\
\text { the individual arrangements of the } \\
\text { regulatory agency. }\end{array}$ \\
\hline Mexico & $\begin{array}{l}\text { The Federal Commission for Regulatory } \\
\text { Improvement (COFEMER) under the } \\
\text { Ministry of Economy is responsible for } \\
\text { the scrutiny and championing of RIA. }\end{array}$ & $\begin{array}{l}\text { Agencies and decentralized bodies of the } \\
\text { Federal Public Administration as well as } \\
\text { states and municipalities are responsible } \\
\text { for promoting RIA. }\end{array}$ \\
\hline
\end{tabular}

Mexico, COFEMER organized, with the help of the OECD, 17 training sessions in 2010 at the federal and municipal level - these were attended by 476 officials (OECD, 2013, p. 69). Cambodian officials embarked on study tours to Australia, Vietnam and the UK (Nolson, 2014). These types of training activities, however, were not always sustained after the international programmes and donors disappear, despite attempts in some countries (e.g. Uganda) to build the capacity of local training institutes to support RIA training needs (see ICAS, 2010b). 


\section{Transparency and stakeholder consultation}

One of the most important functions of RIA systems is to increase the openness and transparency of policy making. Involving stakeholders in consultation is one way to do this (see below). Another is to publish the RIA reports systematically on a single website so that they can be easily located and scrutinized by external stakeholders. Table 4 summarises the availability and accessibility of the RIA reports in the different countries. Only in three cases are the RIAs reports made available (in principle at least) in an easily accessible central online location (Mexico, Cambodia and Malaysia). In other countries the RIA reports are difficult to find online and in many cases are not available at all.

Table 4. Availability and accessibility of RIA reports

\begin{tabular}{|c|c|}
\hline Country & Availability and accessibility of RIA reports \\
\hline \multicolumn{2}{|l|}{ Africa } \\
\hline South Africa & $\begin{array}{l}\text { The RIAs are not systematically published online and are very hard to locate. Many } \\
\text { RIA reports are not published at all. }\end{array}$ \\
\hline Tanzania & The few RIA reports produced were not widely published. \\
\hline Uganda & The few RIA reports produced during the RBP programme were not made public. \\
\hline \multicolumn{2}{|r|}{ (2: } \\
\hline Cambodia & $\begin{array}{l}\text { RIA reports are listed (in English and in Khmer) on a central website but the links to } \\
\text { the documents were not in place: http://wwwecosocc.gov.kh }\end{array}$ \\
\hline Laos & $\begin{array}{l}\text { Several preliminary RIAs are available (in English) online but not on a central } \\
\text { website. }\end{array}$ \\
\hline Malaysia & $\begin{array}{l}\text { The newly launched RIA portal does not yet list any RIA reports but should contain } \\
\text { all RIAs in future. http://ris.mpc.gov.my/?page_id=661 (Prior to } 2013 \text { there were } \\
\text { only a limited number of RIA reports were produced). }\end{array}$ \\
\hline Philippines & $\begin{array}{l}\text { Where 'approved for release', all final RIA documents are to be published on the } \\
\text { pilot department's website. }\end{array}$ \\
\hline Vietnam & Some RIA reports are available online. \\
\hline \multicolumn{2}{|l|}{ Latin America } \\
\hline Brazil & $\begin{array}{l}\text { Some RIAs for the pilot Pro-Reg project have been made public but not on a } \\
\text { centralized website. Inmetro has published summaries of the RIA reports on its } \\
\text { website: http://www.inmetro.gov.br/qualidade/iaac/eiv.asp }\end{array}$ \\
\hline Mexico & $\begin{array}{l}\text { All RIA reports are available on the COFEMER webpage: } \\
\text { http://www.cofemermir.gob.mx/mir/ }\end{array}$ \\
\hline
\end{tabular}

Consultation with affected stakeholders and the public provides, among other things, a cost-effective way (and often the only way) to gather the information needed to assess impacts in data poor environments (World Bank, 2009). Stakeholder consultation is incorporated, in principle, into all the RIA systems included in the survey (see Table 5). In some cases (Philippines, Vietnam, Brazil (ProReg) and Mexico) the proposals are published online and a minimum time period for public comment is stipulated. In practice, however, there is evidence that the consultation procedures instituted in the RIA documents are not well performed. In particular, there is a lack of standardized consultation procedures. Instead, stakeholders are often consulted on an ad hoc basis, frequently through personal contacts with a minister or senior civil servant, or informal meetings with government representatives. For example, in Uganda a number of gaps in the dialogue framework have been reported and opportunities for external input from 
civil society or business organizations is therefore thought to be limited (interview 4; ICAS, 2010b). In South Africa, consultation is left up to the lead department and the consultants that they commission - some are more proactive and accustomed to consultation than others (interview 1 ; interview 3 ).

Table 5. Provisions for stakeholder involvement in RIA

\begin{tabular}{|c|c|}
\hline Country & Provisions for stakeholder involvement \\
\hline \multicolumn{2}{|l|}{ Africa } \\
\hline South Africa & $\begin{array}{l}\text { Stakeholders should be consulted but this is not mandatory and left up to the } \\
\text { individual consultants conducting the RIA. }\end{array}$ \\
\hline Tanzania & Consultation of stakeholders encouraged. \\
\hline Uganda & Consultation of stakeholders but in practice this can be limited. \\
\hline \multicolumn{2}{|r|}{ 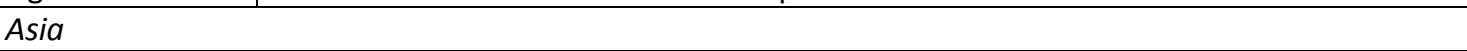 } \\
\hline Cambodia & $\begin{array}{l}\text { Consultation of stakeholders strongly encouraged (specifically: industry, consumers, } \\
\text { government departments and gender groups). Draft regulatory proposal is } \\
\text { published online. }\end{array}$ \\
\hline Laos & 60 days for public comment required by the 2012 Law on Making Legislation. \\
\hline Malaysia & $\begin{array}{l}\text { Consultation of stakeholders (specifically: business, NGOs, communities, other } \\
\text { government agencies). }\end{array}$ \\
\hline Philippines & $\begin{array}{l}\text { Consultation of stakeholder groups affected by regulations, minimum of } 30 \text { days for } \\
\text { public comment. }\end{array}$ \\
\hline Vietnam & Draft regulatory proposal is published online, 60 days period for public comments. \\
\hline \multicolumn{2}{|l|}{ Latin America } \\
\hline Brazil & $\begin{array}{l}\text { For Pro-Reg, stakeholder consultation is mandatory, minimum of } 60 \text { days for public } \\
\text { comment. Inmetro hold online consultations as well as meetings and visits with } \\
\text { stakeholders. }\end{array}$ \\
\hline Mexico & $\begin{array}{l}\text { Draft regulatory proposal is published online, minimum of } 10 \text { days for public } \\
\text { comment. }\end{array}$ \\
\hline
\end{tabular}

\section{Tools and methods}

Tools and methods such as cost-benefit analysis (CBA) or multi-criteria analysis which help assess the likely impacts of policy options are increasingly being used, or at least encouraged, in RIA systems in OECD and EU member states (Jordan and Turnpenny, 2015). However, this proved one of the hardest areas of the survey to gather information on. While the guidance documents in some countries included information on tools, there was little evidence of their actual use in practice. CBA is the tool most commonly mentioned in RIA guidelines. In South Africa, it is stated that the major costs and benefits of the proposal should be quantified where feasible (The Presidency, 2012, p. 22). This should include full economic costs and benefits including social, environmental, and health and safety costs and benefits. In Mexico both, costs and benefits are to be quantified and monetarised (OECD, 2013). In the Philippines, CBA is not required in a preliminary RIA but is regarded to be useful to assess the significance of impacts (Department of Finance et al., 2012). A detailed CBA is however required in a full RIA - although it is acknowledged that not all impacts may be quantifiable (ibid). In Cambodia, the requirement of a CBA made in the RIA guidelines is backed up a CBA unit in the central Office of Regulatory Impact Assessment which supports ministries in making the necessary calculations (Nolson, 2014). 


\section{Quality of RIA}

Many of the countries included in the survey have only recently established, or are still in the process of establishing, institutional frameworks for RIA. However, independent evaluations of the quality of RIA could still be found for four cases. An evaluation of RIA in South Africa published in 2011 found that the few pilot RIAs were done mostly by consultants in an ad hoc fashion (Truen, 2011). Furthermore, the RIAs were reported to have come too late in the policy making process, and had little effect on the policy proposals (ibid). An evaluation of the framework for Better Regulation (including RIA) in Uganda claimed that the capacity to pursue regulatory reform (including RIA) had not developed since the end of the donor funded project, primarily because of a lack of funding (ICAS, 2010b, p. xi). In Mexico, which is the 'oldest' of the RIA systems under investigation, an OECD report found that only seven of the thirty-one Mexican states were implementing RIA in practice 'with wide variation in terms of the stage of adoption and sophistication' (OECD, 2013, p. 25). Finally, a review of the implementation of RIA in Vietnam between 2009 and 2010 reported that the quality of RIA reports was low with an average score of just over one out of four (CIEM and USAID, 2011).

Considerable barriers appear to limit the quality of RIA in these developing and emerging economies. While it is beyond the scope of this article to explore these challenges in depth, a number were highlighted in this survey. One of the main barriers was a lack of institutional capacity - despite the efforts in some cases of substantial training programmes supported by international donors. In many countries, the central RIA unit is staffed only by a few officials and is not large enough to obtain the 'critical mass' needed to successfully champion RIA across government. In Uganda, a difficulty in attracting and retaining high-quality staff at the pay levels available also meant that plans to increase and train the staff in the RIA units in some cases was slow to progress (Welch, 2007, p. 220). Similarly, in Mexico officials and RIA experts within Ministries occupy often a position just for a few years and can then be replaced by the incoming team of a newly elected political party (Interview 5). In South Africa, the lack of institutional capacity is, in part, overcome by the use of external consultants to carry out RIAs but this has led to a lack of ownership and the almost complete separation of RIA from the decision making process.

Further investment in training for civil servants and other key stakeholders is therefore frequently recommended for improving the quality of RIA (e.g. Vietnam, South Africa, Mexico). However, the more fundamental issue is the time horizon over which these activities take place. Institutionalising RIA has proved to be a long term commitment and ensuring the sustainability of RIA systems over the medium and long-term is a major challenge. Even in Uganda where DIFID's standard threeyear programme period was replaced with two back-to-back programmes spanning six years (2000-2006) difficulties were still experienced after the initial period of effort and funding ended. Another challenge frequently reported in the country cases is how to develop and implement assessment tools and methods in an environment where information and quantitative data is not readily available or can 
only be secured by extraordinary efforts (ICAS, 2010b). A lack of data and analytical skills was reported as a problem in many of the countries in the survey (Tanzania, South Africa, Uganda, Mexico and Brazil). Furthermore, poor consultation practices reduce opportunities to plug this data gap.

\section{Conclusions}

In principle RIA has the potential to contribute to the good regulatory governance and improve the business environment of developing and emerging economies. This survey provides the most up to date and systematic review currently available of the adoption and implementation of RIA in these countries. The findings suggest that, although RIA is being applied in a number of developing and emerging economies, its use is by no means widespread or well institutionalised. The survey has not attempted to cover a statistically representative sample and therefore does not aim to quantify what proportion of developing countries have established, or are in the process of establishing, RIA. If anything, it is highly likely that the number of countries with RIA systems or in the process of establishing RIA systems is over represented in the results of the survey as, when selecting case countries, researchers were more interested in recording what was there rather than what was not.

Given the above caveat, the survey reveals a dynamic regulatory governance landscape in which the adoption of RIA is playing an increasing role: eight of the countries included in the study have introduced RIA in the last ten years while one other country (Malaysia) has recently redesigned its existing RIA system. Only one country (Mexico) has a long-standing RIA system in place. However, the survey finds that in the majority of cases RIA still remains at an early stage of development while six countries out of 16 , including China and India, do not (yet) practice RIA. In this sense, the diffusion of RIA in developing and emerging economies has not been as rapid as perhaps might have been expected considering the almost universal spread of RIA in OECD and EU member states during the last decade: By 2012, 33 out of the 34 OECD countries had adopted RIA while a survey conducted in 2010 of 17 European countries found that all 17 had adopted some form of policy assessment system, although some countries were still in the early stages of implementation ((Arab African Advisors, 2015; Adelle et al., 2011). Furthermore, the lack of widespread diffusion of RIA in the developing countries is apparently despite the best efforts of international actors such as the OECD, World Bank, regional development banks and the aid programmes of countries. Many of these actors (such as the UK and US) have well developed RIA systems themselves.

These findings are also rather surprising considering that ten years ago Kirkpatrick et al. (2004) already reported the application of RIA in 30 developing countries. It is possible that differences in survey methodology as well as focus of study can help explain this apparent discrepancy. Kirkpatrick et al. collected data through selfreported questionnaires, which they admit at times yielded ambiguous and conflicting responses. In contrast, the survey reported in this article was based on indepth case studies compiled by researchers using a variety of data sources. While 
this methodology had the disadvantage of reducing the number of countries which could be included in the survey, it did avoid the potential danger of (overly) positive self-reporting. Furthermore, the current survey looked for evidence of RIA within a wider supporting framework (i.e. 'RIA systems'). The respondents in Kirkpatrick et al.'s survey may have reported the occurrence of RIA even if it had been applied only a few times on an ad hoc basis (i.e. 'RIA events'). Thus, while this latest survey does not necessarily find evidence for a rapid diffusion of RIA, it does point to a greater institutionalisation of RIA in the policy making process in some developing countries over the last ten years. In this sense RIA in these developing countries is following the path of RIA in developed countries (if only slowly in places) where increasing institutionalisation of RIA over time has been reported in the older RIA systems such as in the UK, the Netherlands and Denmark (Adelle et al., 2011).

The proper institutionalisation of RIA in developing countries is important if RIA is to live up to its potential to contribute to good regulatory governance and ultimately economic growth and poverty reduction. Many of the same key elements thought to be crucial in embedding RIA into the policy making process in developed countries are at least recognised in principle in the RIA systems of the developing and emerging economies analysed in the survey. These include: legal, or at least high level, support for RIA; the incorporation of stakeholder consultation; and the establishment of a central RIA unit to coordinate and champion RIA across government. In many cases, RIA systems have also been supported, at least initially, by substantial training programmes.

Many challenges, however, were found in the operationalization of these key elements of RIA in practice, such as a lack of institutional capacity as well as sustained financial and political support. Although these challenges may not be substantially different from those facing RIA in developed countries, they are often of a different order of magnitude (Adelle et al., 2015). Furthermore, ownership of RIA can at times be inhibited in developing countries by the perception that RIA is imposed by the international donor community (ibid). In these circumstances RIA can become just another box to tick. Certain RIA elements, such as stakeholder consultation and transparency, appear to be areas of under performance in developing countries compared to OECD and European countries (e.g. Adelle et al., 2011). These elements of RIA may prove to be particularly hard to institutionalise in countries where governments are perhaps less comfortable with these aspects of inclusive governance.

Only in Mexico does RIA appear to be relatively well institutionalised with a system that is roughly comparable to those found in developed countries - something which is perhaps not surprising considering Mexico is an OECD country. Even then, a report by the OECD has uncovered a wide variety of stages of adoption and sophistication within this RIA system (OECD, 2013). Crucially, and in common with many other OECD countries, some form of 'pre-RIA' has been practiced in Mexico since the early 1990s until the more contemporary form of RIA was introduced around 2000. In some cases, such as Malaysia, the government has undertaken considerable efforts to sustainably implement RIA but it is just too early to tell how well the new system 
will be implemented. While for other countries, such as South Africa, Tanzania and Uganda, it appears that RIA systems have not taken root as anticipated, despite considerable investment of resources and expertise.

This snap shot of RIA in developing and emerging economies is not intended, however, to induce a sense of pessimism. The history of RIA in OECD and EU member states has already demonstrated that RIA systems take time (often many decades) to get 'right': Policy assessment apparently spread from the US only slowly at first, with the Finland and Canada adopting some form of policy assessment system in the 1970s and Australia, the UK, the Netherlands and Germany following in the mid 1980s (OECD, 2009). A rapid rise in adoption of policy assessment systems in OECD and European countries only followed in the second half of the 1990s following an OECD recommendation on regulatory reform (OECD, 1995). Even then, the implementation of RIA in practice in most developed countries is often considered to be varied at best (see Adelle et al., 2012). While the institutionalization of RIA in developing and emerging economies may take considerably longer and require more effort than first assumed (particularly by international donors and organisations), the potential benefits for good regulatory governance are, it could be argued, worth waiting for.

\section{References}

Adelle, C., et al., (2011), Impact Assessment Practices in Europe [online]. LIAISE Innovation Report no 2. Available from: http://edocs.fuberlin.de/docs/servlets/MCRFileNodeServlet/FUDOCS_derivate_000000001582/L IAISE_innovation_report_n02.pdf;jsessionid=2DE4E6CABA82B3806390B7AA453A 8B55?hosts $=$ [Last accessed April 2015].

Adelle, C. and Weiland, S. (2012), Policy assessment. Impact Assessment and Policy Appraisal, 30, 1, p. 25-33.

Adelle, C., Jordan, A. and Turnpenny, J. (2012), Proceeding in parallel or drifting apart? A systematic review of policy assessment research and practices. Environment and Planning C, 30, 3, p. 400-414.

Adelle, C., Macrae, D., Marusic, A. and Naru, F. (2015) New development: Regulatory impact assessment in developing countries-tales from the road to good governance, Public Money and Management, 35, 3, 233-238.

APEC Economic Committee (2009), APEC Economic Policy Report 2009. Singapore. http://publications.apec.org/publication-detail.php?pub id=942 [last accessed July 2014]

Arab African Advisors (2015), Facts and figures. Governance Observer, 2(11), 3.

CIEM \& USAID (2011), Evaluation of regulatory impact assessment implementation in Vietnam, 2009 - 2010. CIEM \& USAID. Available from: http://www.businessenvironment.org/dyn/be/docs/218/Final RIA Review Vietn am.pdf [Last accessed June 2014]

Department of Finance, Department of Labour and Employment, \& Department of Tourism. (2012), Draft: Regulatory Impact Assessment (RIA) Guidelines. Philippines

RIA Pilot

Program.

Available

from 
http://www.tourism.gov.ph/Downloadable

Files/Philippines Pilot RIA Guidelines Draft v4 23 July 2012.pdf

[Last accessed June 2014]

Hamsa, A. Bin (2013), Speech by YBHG. Tan Sri DR. Ali Bin Hamsa, Chief Secretary to the Government, 15 July 2013. http://ris.mpc.gov.my/wpcontent/uploads/2013/07/KSN-Speech-National-Policy-On-The-Development-

And-ImplementatiOn-Of-Regulations.pdf [Last accessed March 2014]

Investment Climate Advisory Services of the World Bank Group (ICAS) (2010a), Better Regulation for Growth: Regulatory Capacity Review of Tanzania, (The World Bank Group).

Investment Climate Advisory Services of the World Bank Group (ICAS) (2010b), Better Regulation for Growth: Regulatory Capacity Review of Uganda, (The World Bank Group).

Jordan, A.J.; Turnpenny, J.R.(eds) (2015), The Tools of Policy Formulation: Actors, Capacities, Venues and Uses. (Edward Elgar).

Kirkpatrick, C. (2015), Regulatory impact assessment: diffusion among developing countries, In: Radaelli, C. and Dunlop, C. (eds) Handbook of Regulatory Impact Assessment (Edward Elgar) (in press).

Kirkpatrick, C., Parker, D. and Zhang, Y.F. (2004), Regulatory impact assessment in developing and transition economies: a survey of current practice. Centre on Regulation and Competition Working Paper Series, Paper No 83.

Nolson, Y. (2014), Regulatory Impact Assessment Experiences in Cambodia, Paper presented at the OECD South East Asia Forum, 25-26 March, Bali, Indonesia.

OECD, Organization for Economic Co-operation and Development, (1995), Recommendation of the Council of the OECD on improving the quality of government regulation. Paris: OECD.

OECD (2008), Building an Institutional Framework for Regulatory Impact Analysis (RIA): Guidance for Policy Makers. OECD Publishing, Available from: http://www.oecd.org/regreform/regulatory-policy/40984990.pdf [Last accessed June 2014]

OECD (2009), Indicators of regulatory management systems. OECD Publishing, Available from: http://www.oecd.org/gov/regulatory-policy/39954493.pdf [Last accessed April 2015].

OECD (2013), OECD reviews of regulatory reform. Mexico: towards a whole-ofgovernment perspective to regulatory improvement. OECD Publishing, Available from: http://www.oecd.org/gov/regulatory-policy/Mexico-Review-of-RegulatoryReform-2013.pdf [Last accessed March 2014].

OECD (2014), Development Co-operation Directorate (DCD-DAC): DAC Members, Available from: http://www.oecd.org/dac/dacmembers.htm [Last accessed April 2014]

Opio-Lukone, V. (2008), Presentation to the conference 'Cutting red tape in Eastern Africa sharing approaches to regulatory reform'. December 3-5, 2008 - Arusha, Tanzania.

Parker, D. and Kirkpatrick, C. (2007), Regulatory impact assessment in developing countries. In: Kirkpatrick C, Parker D (eds) Regulatory impact assessment: towards better regulation? (Edward Elgar). 
Radaelli, C., Dente, B., Jacobs, S., Kirkpatrick, C., Meuwese, A., Renda, A. (2006), Handbook for DIADEM Data Collection.

SBP (2005), Investigation of the possibilities for regulatory impact analysis in South Africa, Executive Summary phases 1 - 3. Report prepared for the presidency and the National Treasury by a consortium led by SBP.

The Office of the President (2005), Evidence Based Policy Making: A Guide to regulatory Impact Assessment. (Cabinet Secretariat, Kampala).

The Presidency (2012), Guidelines for the implementation of the regulatory Impact Analysis/Assessment (RIA) process in South Africa. (The Presidency, Pretoria).

The Presidency (2006), Position Paper on the Implementation of Regulatory Impact Assessment in South Africa. (The Presidency, Pretoria).

Truen, S. (2011), Regulatory Impact Assessment in SADC: Improving Regional Regulatory Outcomes. Consultancy report submitted by AECOM International Development to USAID/Southern Africa. USAID Contract No. 674-C-00-10-0007500 .

Welch, D. (2007), Regulatory impact assessment in East Africa. In: Kirkpatrick C, Parker D (eds) Regulatory Impact Assessment: Towards Better Regulation? (Edward Elgar).

World Bank (2009), Making it Work: 'RIA Light' for Developing Countries. (Investment Climate Advisory Service of the World Bank Group, Washington DC).

World Bank (2013), List of Developing Countries. Available at: http://data.worldbank.org/about/country-classifications/country-and-lendinggroups [Last accessed March 2013]

\section{Referenced Interviews}

Interview 1: Consultant (South Africa), January 2014

Interview 2: Consultant (Brazil), February 2014

Interview 3: Consultant (South Africa), February 2014

Interview 4: Government Official (Uganda), April 2014

Interview 5: Consultant (Mexico), February 2014 